\title{
New Paradigm of Research Management in Higher Education: The Case of Politeknik Negeri Bandung
}

\author{
Carolina M Lasambouw \\ Politeknik Negeri Bandung \\ Bandung, Indonesia \\ carolina.magdalena@polban.ac.id \\ Neneng Nuryati \\ Politeknik Negeri Bandung \\ Bandung, Indonesia \\ nnuryati.polban@gmail.com
}

\author{
Ediana Sutjiredjeki \\ Politeknik Negeri Bandung \\ Bandung, Indonesia \\ e_sutjiredjeki@yahoo.com
}

\begin{abstract}
Based on the enactment of law of the Republic of Indonesia each lecturer is required to do research beside teaching and community services. It is not an easy task for some lecturers in vocational education, such as Politeknik Negeri Bandung/ Bandung State Polytechnic (Polban). The main problem encountered by Polban's lecturers to do research is quite fully loaded teaching duties assigned by their faculties. This condition occurs, as formerly - since the polytechnic founded - the lecturers had no obligation to conduct research. Besides, their career promotion had not been based on their research performances. This paper discusses the strategies and the efforts that have been made by the Polban to increase the numbers of research and scientific publications both on a national and international level. The strategies are developing research competencies standard for lecturers, as well as its evaluation tools. Lecturers were also asked to complete Individual Research Plan (RIP) from which their researches will be accomplished in the next five years based on their experience in research and scientific publications. Then classified the lecturers into three levels, they are: novice researchers, associate researchers and principal investigator. In addition, Polban has been strengthening the research expert groups, as well as preparing the research roadmap. Furthermore, Polban has established an incentive system to reward lecturers who have shown good research. As a result of these strategies, the number of researchers in Polban has increased up to $70 \%$.
\end{abstract}

Keywords-Higher Education, Polytechnic, Research Management, Strategies.

\section{INTRODUCTION}

Based on the enactment of law of the Republic of Indonesia number 12 of 2012 on Higher Education [1], as well as the Ministry of Research, Technology and Higher Education's Decree number 44 of 2015 on National Standards for Higher Education [2], research as one of the three main function of higher education must be carried out by each lecturer. Research obligation is not easy for some lecturers in vocational education, such as in Politeknik Negeri Bandung/Bandung State Polytechnic (Polban). The main problem encountered by the lecturers in Polban to conduct research is quite fully loaded teaching duties assigned by their faculties. This condition occurs, as formerly - since polytechnic founded - the lecturers had no obligation to conduct research. Besides, most of the lecturers' career promotion in Polban had not been based on their research performances. Therefore, it is not easy to push and motivate this group of lecturers to fulfil the research obligation.

Since 2011 some efforts have been made to increase the number of lectures in each faculty in Polban to conduct research. Although not all lecturers in Polban have been carrying out research activity, but gradually the number of lecturers who are conducting research increased significantly. Along with the increasing number of research activities carried out by the lecturers, the lecturers have produced a number of scientific publications and some scientific journals had also been published, both in nationally accredited journals and indexed national journals.

This paper discusses the strategies and efforts that have been made by the research management in Bandung State Polytechnic to increase the number of lecturers to conduct research and to increase the number of scientific publications, both on a national and international level. Further, discussion will be focused on research activities that have been completed in the framework of these efforts. Research methodology, research results, and the discussions will be elaborated in the second and third sections of this paper. Finally, the conclusion will be presented in section four.

\section{ReSEARCH Methodology}

The strategy chosen to increase the number of lecturers' research activities in Bandung State Polytechnic focuses on enhancing lecturers' capacity to conduct research. Enhancing researchers capacity has been studied by several former investigators [3], [4], [5], [61], [7] and [8]. The fundamental differences between this study and previous researches in this 


\section{Asuneses PRESS}

topic are on the focus of the study. This study focused on the research management strategies in the higher vocational education institutions, which generally have different problems, and challenges compared to other higher education institutions such as universities or institutes. In addition, this study takes into account that strengthening lecturers' research capacity is an integral part of research management function played by the research unit within the institution. Thus the role of leadership in the research unit is very important [9].

This study uses two approaches, qualitative and quantitative approaches. A qualitative approach was used to identify alternative models of capacity development resulted from previous studies. The methods used are literature review, Focus Group Discussion and interviews with purposeful respondents. Furthermore, the identified model was confirmed and validated through quantitative approach. In line with the purpose of this research, the capacity development model is also validated by expertise judgment.

In the quantitative approach, 69 respondents participated in filling in the questionnaires distributed in random among lecturers in Bandung State Polytechnic.

\section{RESULTS AND DISCUSSION}

The implementation of strategies and efforts to improve the lecturers' research competencies was conducted step by step. The initial step is to develop competency standards for lecturers in Polban in conducting research. It is complemented with the evaluation tools. Based on the competency standards, mapping the lecturers' competencies that have conducted research and scientific publications was completed. The result of mapping 69 participants' research abilities is shown in Figure 1 below.

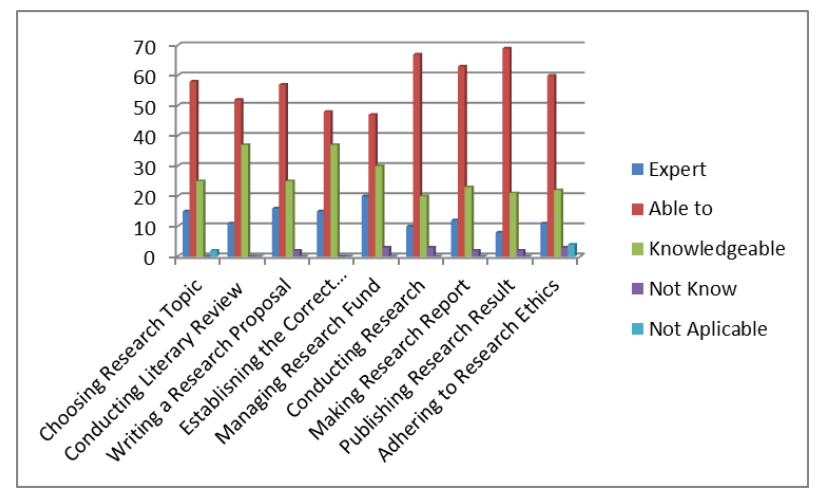

Fig. 1. Mapping of Lecturers Competency in Conduct Research

The figure shows that most lecturers have research capabilities as Able to and Expert. However there are a number of lecturers (37\%) stated their research capabilities at Knowledgeable. This means that the research management in Bandung State Polytechnic needs to implement effective strategies in order to raise the research capabilities of those lecturers' with lower research ability.

Data obtained from the activity is used to develop a Framework/Model of Research Capacity Development for
Polytechnic Lecturers. It includes the aspects of research management as shown in Figure 2.

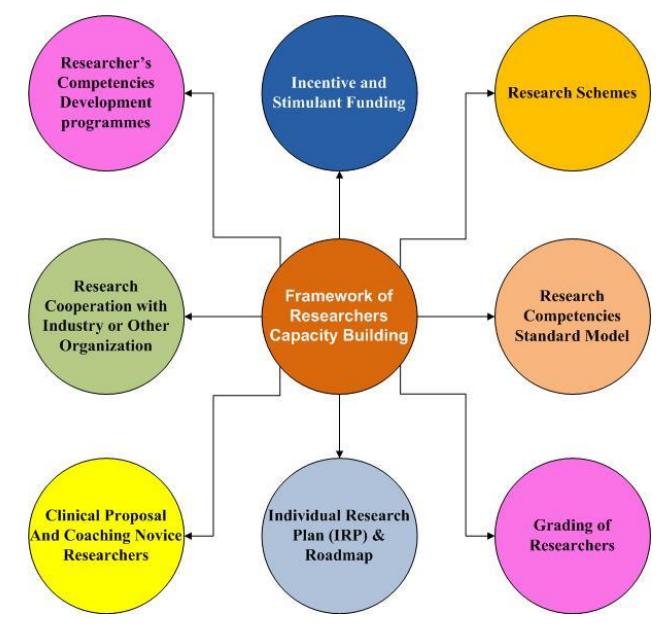

Fig. 2. Researchers Capacity Development Elemens

The Framework of Researchers Capacity Building consists of eight (8) elements, which are linking to each other. The first element is developing Researchers Competencies Standard. Currently 16 (sixteen) unit of researchers' competencies were developed and had been used for assessment and developing training programs such as to develop researchers skills in making proposal. Clinical Proposal is provided to support lecturers who need consultation and coaching on their research proposal.

The fourth element is encouraging lecturer to develop Individual Research Plan \& Roadmap. This element is need due to a consideration that academic researchers usually consider themselves free, within the limits of legality and ethics, to research whatever topic they choose [10]. In this element the lecturers were asked to fill in an Individual Research Plan (IRP) form, which is to be implemented in the next five years. This form contains data of lecturer experiences in research activities and scientific publications.

The fifth element is building Grading of Researchers. Based on the Individual research Plan, Roadmap and other relevant information/data, lecturers will be graded into three ranks: novice researchers, associate research professor and principal investigator. Novice researchers are lecturers that have done research with maximum budget allocation of Rp.30.000.000, per year, either from an independent funding source, Polban Institutional budget, as well as from research scheme in Higher Education. Novice researchers have grading 0-3. Associate Research Professor is a group of lecturers who have done research with maximum budget allocation Rp.80.000.000, - per year both from sources such as Polban Institutional budget, applied research scheme, development research or innovation schemes, as well as from research in Higher Education scheme, such as Applied Product research, Fundamental research scheme or from other external sources. Associate Research Professor has intermediate grading 4-6. While Principal Investigator is a group of lecturers who have done research with a budget allocation above Rp. 80.000.000, - per year such as from National Strategic research schemes, Grant 


\section{$\triangle$ ATLANTIS PRESS}

Competence, Cooperation scheme of study abroad. The Principal Investigator researchers have top grading 7-9.

The sixth element is Provision of Specific Research Schemes; especially to support internal research policy such as escalates Competitiveness of Scientific Expertise Group, and strengthening the capacity of laboratories.

Element seven is provision of a number of incentive and stimulant funding as a reward for researchers' achievement such as incentive for a research article that is published in national accredited journal and indexed international journal; incentive for new textbooks based on research results; and provide funding support for attending national and international seminars.

Element eight is expanding Research Cooperation with industry, university or other organization at national and international level. As a first step this element is built through alumni network, especially graduates of universities abroad.

\section{CAPACITY BUILDING FRAMEWORK}

There are two conceptual model proposed for capacity building. They are the Capacity Building Models with hierarchical (vertical) approach and capacity building through Chain Process Approach [11].

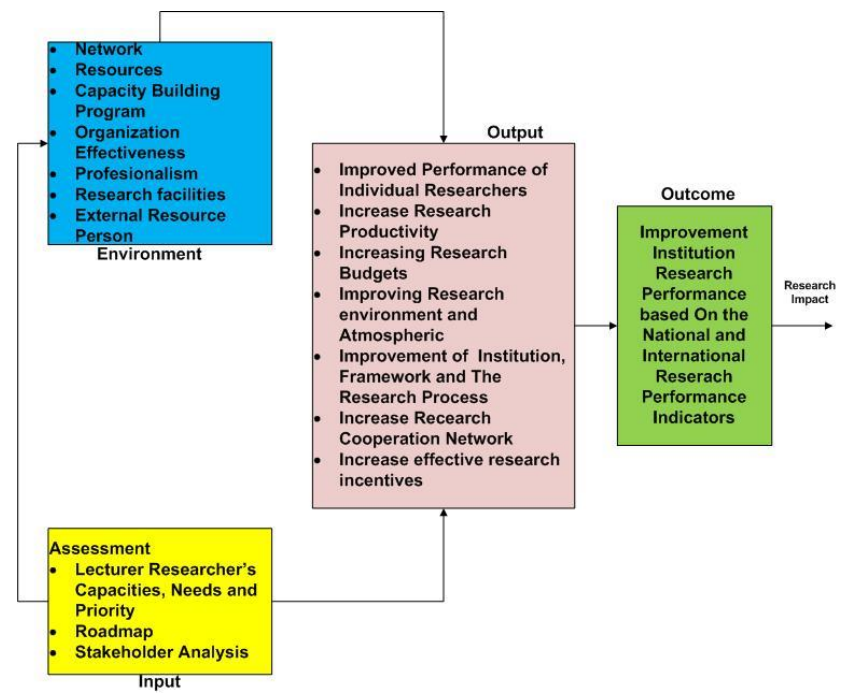

Fig. 3. Chain Process Model of Capacity Building

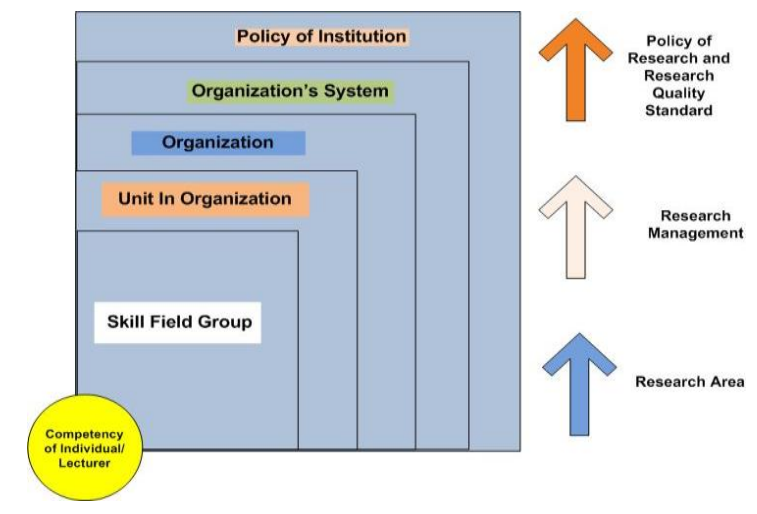

Fig. 4. Hierarchical Model Capacity Building
Both capacity building models complement each other. To increase the performance of research institutions, the development of capacity in the hierarchy can be used as an evaluation model. The chain process model of capacity building is more suitable for increasing the performance of individual researchers. It contains a number of variables that are interrelated. The capacity it contains some of the variables that are interrelated. Within the capacity building process the researchers must integrate variables relating to the research implementation. In the process of conducting research there are a series of activities that need to be carried out by the researcher. This process is known as the cycle of research (research cycle), or also known as the spectrum of research. [12], [13], [14], [15]. In the process of capacity building as Figure 3 shown there are at least three major aspects of input, output and outcome.

Assessment aspect is the main input in the process of capacity building. Therefore, to discover individual research performance, an assessment of research capacity development is carried out. Four aspects are used as basis, namely intellectual ability, personal effectiveness, organization and management, as well as the participation and impact of the research results. This is shown in Figure 5.

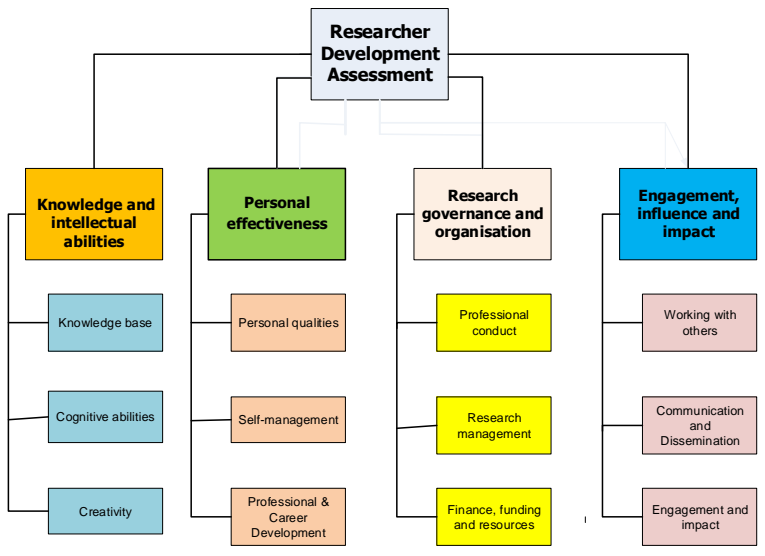

Fig. 5. Aspects of Researchers Development Assessment

Based on the results of assessments training was developed for strengthening research capacity. As a trial, it is developed a training program for young lecturers in developing research proposal. The training is a package as figure 6 below:

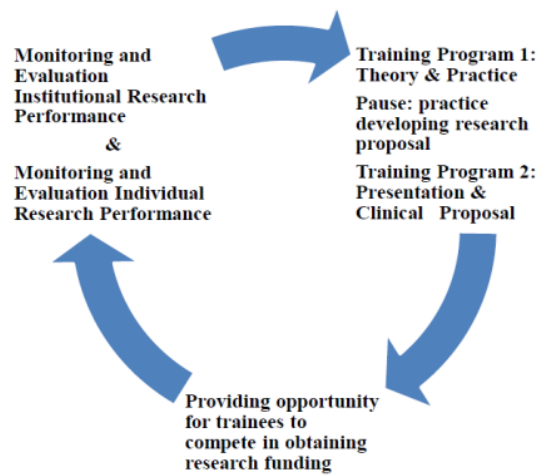

Fig. 6. Steps of Training Program for Young Lecturers 
The training program is developed specifically to strengthen the lecturers' research skills in preparing research proposal. The program is divided into two parts. In part one, the participants who are mostly young lecturers is given theories on developing research proposal and practical exercise. Between training part one and two; there is a week of break time given to the participant for preparing their research proposals. At the second part of training, time is given to the participants for presenting their research proposal. A numbers of reviewers are available to provide comment for improvement and time for consultation (Clinical proposal). Furthermore, after the training is completed, research management unit is providing opportunity for the trainees to submit their research proposals in competition for obtaining research funding.

The result of training for young lecturers is as shown in Figure 7 below.

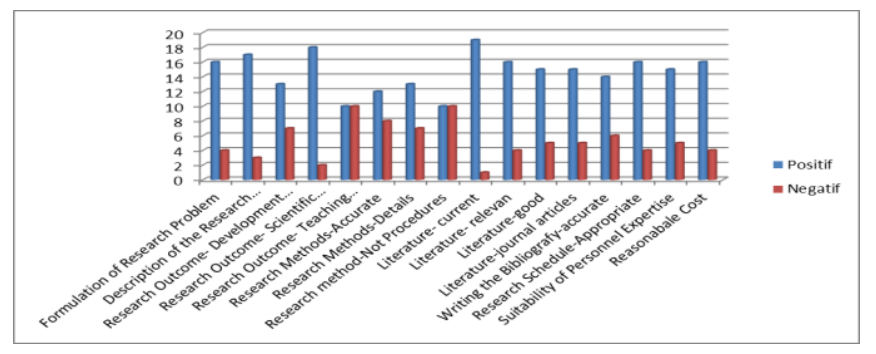

Fig. 7. Result of Training Program for Young Lecturers

Figure 7 shows that the capabilities of the trainees are improved. However in some parts, they're still a need to redevelop, especially in dealing with research outcome on teaching materials.

In terms of the research proposal competition in obtaining funding support, from 20 training participants, 18 lecturers submitted their research proposals. And 15 out of 18 proposals have received funding support from the institution.

In addition to the above strategies, research management in Bandung State Polytechnic provides program to strengthen groups of expertise in the faculties by developing research scheme specifically to strengthen their competitiveness and develop a research roadmap based on the group major expertise. The current program is implementing rewards and incentives system for lecturers who show good performance in research and community services.

\section{CONCLUSION}

In principle, a successful capacity building for lecturer should consider the following things:

1. Capacity building is a continuous process,

2. Focus to strengthen the ongoing process,

3. Involve all interest stakeholders,

4. Involving support and the role of external experts,

5. Ability / core competencies of researchers should be evaluated from the outset to determine if there is a gap that must be addressed immediately. The ability and the resources needed are evaluated periodically.

6. The involvement an commitment of all management and leadership, as well as the necessary organizational development,

\section{Clear development of group membership.}

As a result of these efforts, in 2016 the number of lecturers who are conducting research in Polban had increased. Currently, approximately $70 \%$ of lecturers in Polban have conducted research, and will continue to be pursued so that by the end of 2017 the number of lecturers who conduct research can reach $90 \%$.

\section{ACKNOWLEDGEMENT}

The authors are very grateful to the management of Research and Community Services Unit in Politeknik Negeri Bandung who have supported this research. Appreciation and thank you also conveyed to the Polban's lecturers who have provide information for this research. Further thanks are also extended to the students who have participated in filling out the online research questionnaire.

\section{REFERENCES}

[1] Law of the Republic of Indonesia Number 12 Year 2012 on Higher Education.

[2] Ministry of Research, Technology and Higher Education of the Republic of Indonesia Decree Number 44 of 2015 on National Standards for Higher Education.

[3] A. Ghaffar, "Research capacity strengthening in low- and middleincome countries, Council on Health Research for Development (COHRED)," www.cohred.org/downloads/cohred.../Changing_Mindsets.pdf, 2013.

[4] Deparment For International Development (DFID), "Capacity Building in Research," in http://HTN_Capacity_Building_Research_Final_21_6_10.pdf, 2010.

[5] J. Hailey, R. James, R. Wrigley, "Rising to the Challenge: Assessing the Impacts of Organizational Capacity Building INTRACT," in http://www.intract.org/pages/PraxisPaper2.html, 2005.

[6] Vogel, "Activities to Build Scientific Capacity in Developing Countries," in www.ukcds.org.uk/.../UKCDS_Capacity_Building_Report_July_2012.p d, 2012.

[7] F. White, "Capacity Building for Health in Developing Countries," in www.scielosp.org/scielo.php?pid=S1020-49892002000900004, 2002.

[8] M. Ford, "Mechanism for Building Research Capacity in Indonesia," in https://dfat.gov.au/.../building-indonesian-research-capacity-austuniversity, 2012.

[9] T. Elkins, T.K. Robert, "Leadership in Research and Development Organization: A Literature Review," in https://faculty1.coloradocollege.edu/.../Elkins Keller Literature review, 2003.

[10] A.M. Johnson, Professor, Improving Your Research Management, Netherlands: Elsevier B.V, 2013.

[11] C. Lasambouw, E. Sutjiredjeki, N. Nuryati, "Development of Competency Standard Model for Researchers to Improve Research Capacity in Indonesia Polytechnic Lecturers," in International Journal of Education and Research", Vol 3 Number 12, pp.53-62, December 2015.

[12] J.H.McMillan and Schumacher.S, Research in Education: A Conceptual Introduction. New York: Longman, 1997.

[13] Creswell.J.W, Educational Research: Planning, Conducting and Evaluating Quantitative and Qualitative Research, 3rd ed., New Jersey: Pearson Education. Ltd, 2008.

[14] Sugiyono, Metode Penelitian Kombinasi., Bandung: Alfabeta, 2011. 
